\title{
Reflections on educational technology research and development
}

\author{
Jonathan Michael Spector ${ }^{1}$ (D)
}

Published online: 2 November 2017

(C) Association for Educational Communications and Technology 2017

\begin{abstract}
I have asked my co-editors at Educational Technology Research \& Development $(E T R \& D)$ for an opportunity to share a few reflections as my 15 years of service as $E T R \& D$ Development Editor draws to a close. These few remarks represent my reflections about some of the things I have observed over the years. The categories into which I have chosen to group these reflections are: (a) writing, publishing, and editing; (b) instructional design and technology research; and (c) attitudes and abilities. The main messages I try to convey are: (a) simple, descriptive language tends to promote understanding, (b) advocacy can easily lead to overpromising and loss of confidence in our professional discipline, and (c) humility and open-minded inquiry are essential for learning and instruction. Some of these remarks may seem disconnected and unnecessarily personal. That is a risk one takes when trying to express what one genuinely believes. I do hope these thoughts will provoke others, as I have been provoked to learn more and more over the years.
\end{abstract}

Keywords Critical thinking · Educational technology · Inquiry learning · Instructional design $\cdot$ Technology integration

I have served as $E T R \& D$ Development Editor for 15 years. Prior to that, I was a reviewer for the Research Section of $E T R \& D$ for a number of years. I have no idea who nominated me to follow Jim Klein as Development Editor, so I am not able to even the score. Jim gave me many useful pointers that first year. In those days, papers were sent to the Editor by authors through regular mail or as email attachments and circulated the same way,

Jonathan Michael Spector

mike.spector@unt.ed; jmspector007@gmail.com;

https://sites.google.com/site/jmspector007/Home/curriculum-vita

1 Department of Learning Technologies, College of Information, University of North Texas, $3940 \mathrm{~N}$.

Elm Street, Suite G 150, Denton, TX 76207, USA 
anonymously of course, to reviewers. I was at Syracuse University when I became Editor, and I kept a large filing cabinet with multiple drawers (one for each year) for the papers and reviews. Steve Ross was Research Editor at that time, and his tenure as Editor lasted 18 years. The Editor comes up for election by the Editorial Board every 3 years for those who might be wondering about that process.

I recall feeling much less than competent the first 2 years as Editor. I was in frequent communication with Steve about what to do in various situations, and he always offered excellent advice. My initial goals were to recruit more international scholars to the Editorial Board and also to encourage more international contributions from outside North America. I did achieve those goals and $E T R \& D$ is now a highly recognized international journal with contributions from all around the world. My initial disposition was that, because $E T R \& D$ is a double-blind peer-reviewed journal, it should be the reviewers and not the Editor who decides which manuscripts are published. In my 15 years, I have managed to maintain that view with only two exceptions out of about 3000 papers reviewed under my supervision-one involving an early paper with regard to the ethical obligations of instructional designers and a later paper involving a very innovative application supported with somewhat weak empirical evidence. In both cases, the reviews were mixed and reviewer comments suggested that those papers had merit in spite of the recommendation to reject them.

One lesson I learned from Steve early on was how to handle revisions. My inclination had been to send a revision back to all of the original reviewers except any who had already recommended acceptance. I thought it would be useful to see if a reviewer who had previously recommended rejection might change that recommendation based on the revision. That tended not to happen and it upset some reviewers. Steve advised me not to include reviewers who had previously recommended either acceptance or rejection when sending a revised paper out for review, and that became my practice for the last 13 years. Still, it is highly valuable to have reviewers shepherd a manuscript through various iterations as most papers go through $2-4$ revisions prior to publication. I believe that only one submission has ever been accepted on first submission with no modifications required; that paper was from Robert M. Gagné whose writing was meticulous. I worked with Gagné for a number of years when I was Senior Scientist for Instructional Systems Research at the Air Force Human Resources Laboratory in San Antonio. I personally observed him write and re-write and carefully consider every word in every sentence that he wrote, occasionally asking for an opinion from others about a particular word or sentence.

My first reflection concerns something I remember hearing Gagné say multiple timesnamely, our job is to help people learn. The goal is not to pile up papers and build a reputation or become famous - the goal is to help people learn. Gagné and his wife Pat exemplified that goal while in San Antonio, as they spent their spare time tutoring disadvantaged inner-city kids in math and other subjects. Having a goal is important. Having the right goal is ever so much more important. This fundamental message will echo through my remaining reflections.

\section{Communication}

I suppose my interest in writing dates back to my early education in Oak Ridge, Tennessee. When I was about 14, I had my first essay published in an international magazine for Jewish youth called the Young Judean (see http://findingaids.cjh.org/?pID=3465265\#a14). In that essay, I coined a word that later informed many of my career choices-worlizen, 
which is a portmanteau for 'world citizen'. My doctoral studies were in philosophy and my supervisor, Ed Allaire, told me to model my dissertation after John Austin's (1962) How to do Things with Words. He also told me that I could not use the word 'it' or other relative pronouns in my dissertation, as those words had a tendency to create ambiguity. In short, I have had a long-standing interest in writing, and I have received a great deal of advice about how to write clearly. The basic goal in communicating is to be understood. One of my philosophy mentors, Oets Kolk Bouwsma, was a master at expressing complex thoughts using simple language. Bouwsma once told me to write so your grandmother would understand.

While I cannot claim to have mastered writing skills, I believe my 15 years as Editor helped me distinguish good writing from poor writing. There is an example of good writing that I used to share with students called "A Game of India" by Nielsen (1978). In that essay, Nielsen tells a multi-layered story constructed around the goal of trying to figure how a winner was determined by people playing a game outside a train station in India in their spare time; the author had no knowledge of the local languages being spoken and could only watch. He watched, formed hypotheses, discovered they were wrong, watched some more, and so on. One layer is simply describing the local culture. The second layer is trying to figure out the rules of that game. Then one of the players comes into his office and passes away. The third layer concerns a variety of perspectives about death. Nielsen tells this complex story using only the simplest, descriptive language. My grandmother would have understood the story and its multiple layers even though she did not have a high school education. The moral to this story is simple - write and talk to be understood.

The International Board of Standards for Training, Performance and Instruction (ibstpi; see http://ibstpi.org/) creates theoretically grounded and empirically based standards and competencies for instructors, instructional designers, evaluators, training managers, and online learners. The methodology involves asking many professional practitioners and members of the user community about the criticality and frequency of particular knowledge, skills, and attitudes that are important for successful performance. Across those various positions, it happens that communication skills (listening, speaking, writing, presenting, etc.) are consistently ranked the most important. The irony is that few programs preparing professionals in those areas embed sufficient emphasis and practice on communication skills, although many department leaders will claim otherwise.

What all of those positions have in common is that they are goal-driven, although the goals vary from being an instructor to being an online learner. Goals are critical. It then becomes important to have the means to determine the extent to which goals have been attained. Another word I invented along the way is WYMIWYG (pronounced 'whim-eewhig'). Yes, it was inspired by the notion of a WYSIWYG word processor-what you see on the screen is what you get printed. My simple-minded notion was that what you measure (by whatever means-qualitative, quantitative, whatever) is what you will know you have attained. Do not guess-collect and analyze indicators and measures. Moreover, when it comes to students, realize that they are often busy and have many other interests. One result is that many students will perform only to the indicated measure. So, it would then make sense to have challenging goals and associated indicators.

Not surprisingly, I drifted away from the thrust of this section on communication. The goal of this section was to pass along my reflections with regard to what makes effective communication in the world of educational technology, and especially from the perspective of papers in $E T R \& D$. First, one should have something to say that is likely to be of interest and value to those with whom one is communicating. I think of this first step as putting the communication in the context of a story. The story one is telling should be compelling, and 
the language used should be clear, coherent, and concise. Here are my $4 \mathrm{Cs}$ of effective communication: compelling, clear, coherent and concise. When telling the story, it is important to make the purpose and scope evident-this is part of having something compelling to say. Why should I read about butterfly migration? Oh, there is something interesting in how monarch butterflies manage to fly from Canada to Mexico and back again. How is that possible? How do they navigate? How far can they fly in a day? How did that ability evolve allowing multiple generations to make the two-way journey?

Why is what one is doing or going to communicate important? What new knowledge or understanding is contributed? What problem is being resolved? When telling the story, create an obvious flow of reasoning from one point to another, giving my grandmother and other readers guideposts and reminders to help them follow the reasoning. Stay focused on the story-be concise-no side trips of the kind to which this author is attracted. Remember the lessons of such examples as "A Game of India" and other compelling pieces such as Bob Dylan's "The Ballad of Hollis Brown” (see http://www.azlyrics.com/ lyrics/bobdylan/balladofhollisbrown.html), or Percy Bysse Shelley's “Ozymandias" (see https://www.poetryfoundation.org/resources/learning/core-poems/detail/46565), or $\mathrm{T}$. S. Eliot's "The Love Song of J. Alfred Prufrock" (https://www.poetryfoundation.org/ poetrymagazine/poems/detail/44212). Why those examples? Because each one addresses a complex point using very simple language. The example from Dylan reminds one that there are others who are suffering and, borrowing a line from his "Ballad of Frankie Lee and Judas Priest" (see https://bobdylan.com/songs/ballad-frankie-lee-and-judas-priest/), the moral is that "when you see your neighbor carrying something, help him with his load, and don't go mistaking paradise for that home across the road." The goal is to help people learn. The point of Shelley's poem is that what we might think of as great works may not be so great after all. What is our goal? To help people learn-not to transform learning and instruction for everyone, everywhere, and for all times. Then there is T. S. Eliot's famous poem with so many memorable lines, including "Do I dare disturb the universe? In a minute there is time for decisions and revisions which a minute will reverse." Dare to help someone learn.

In an unpublished journal entry, Bouwsma wrote this: "Surely your life will show what you think of yourself." Do you think you can help someone learn? I used to think so, but I have grown less certain over the years. My father, Rabbi Joseph Spector, characterized being a rabbi as being a teacher-being "the ear that listens, the voice that encourages, the eye that reflects, the hand that guides, the face that does not turn away." I am not sure I have been so good at those things and have come to settle for a simpler definition of being a teacher-namely, being someone who helps others to have questions. Having a question involves admitting that one does not know and that one is willing to commit time and effort to finding an answer. To find an answer to challenging questions, one must be willing to explore alternatives and to question one's assumptions. Recall Nielsen's "A Game of India." And just how do monarch butterflies manage that journey from Canada to Mexico and back?

\section{Research}

I stumbled quite by coincidence into instructional design and technology research. I had been teaching computer science because there were no jobs in philosophy, and I had become somewhat adept with expert system technology—so adept that I thought I could 
construct an expert system to do almost anything. I was younger and a bit more arrogant in those days. The Air Force Human Resources Laboratory had a call for a summer research project involving an expert system for instructional design. I thought I could do that. After three months, I told the Air Force that building an expert system for instructional design would take years and a lot more knowledge and expertise than I had. Humility sometimes comes slowly. As things happened, the Air Force decided to proceed and eventually hired me to lead the effort. With the help of many brilliant minds, including Bob Gagné, Dave Merrill, Bob Tennyson, Henry Halff, Martha Polson, Charlie Reigeluth, and Harry O'Neil. We designed and implemented two systems - one called GAIDA and the other called XAIDA - details are available in publications at the Defense Technical Information Center (DTIC; see http://www.dtic.mil/dtic/). Guided Approach to Instructional Design Advising (GAIDA) was based on Gagné's (1985) events of instruction and was aimed at extending the abilities of a novice instructional designer. It was later adopted for use in Air Force technical training. Experimental Advanced Instructional Design Adviser (XAIDA) was based on Merrill's Transaction Theory (Merrill et al. 1991) and it was aimed at replacing an instructional designer. XAIDA had success in automatically generating effective lessons for simple declarative and procedural learning tasks.

I learned early in my career that research on instructional design and technology was a great deal more challenging than I initially thought. Given the goal of helping to improve learning, the indicators of success then are based on learning improvements, which are difficult to collect and analyze except for the simplest of learning tasks. Learning can be characterized by stable and persistent changes in what a person knows, believes, and can do (Gagné 1985). Rarely do researchers collect data before, after, and long after to support claims about learning. Moreover, there are many factors other than an instructional design that intervene. I also learned that, while Gagné and Merrill often held somewhat different views (for example, with regard to learner control), they collaborated on an important paper that was published while they were both working on the Advanced Instructional Design Advisor (AIDA) project (Gagné and Merrill 1990) that focused on the need to address whole tasks, which they called enterprises. That important paper was reminiscent of a small book I had chanced upon while studying philosophy-namely, John Dewey's (1910) How We Think. Dewey's early work and the works of Gagné and Merrill are now widely embraced in the form of authentic learning (see, for example, Merrill 2002).

One would be well advised to read about the media debate between Richard Clark and Robert Kozma (Clark 1994; Kozma 1994). What I learned from that debate was that media and technology can provide affordances and possibilities not previously available, but effective use of media and technology was still dependent on good instructional design as well as training and support for those using the technologies. What makes an instructional design good? Remember the goal-help people learn. An effective instructional design is one that can be demonstrated to have a positive impact on learning.

In recent years, my thinking has become even simpler and I express my main thoughts about learning and technology to students in the form of two sayings: (a) it is not about the technology; it's about the learning; and (b) it is not about the technology; it is about the use of the technology. A song I recall from my youth is called "Simple Gifts" sung beautifully by Judy Collins (see https://www.youtube.com/watch?v=kWTDgc96bg8). Where ought we to be? We should be helping people learn.

Yes, I took a detour and lost focus-poor communication on my part. Back to one last comment on instructional design and technology research. Recently I was told by a student that he believed that a particular and popular instructional design model called Analysis, Design, Development, Implementation, Evaluation (ADDIE; see http://www. 


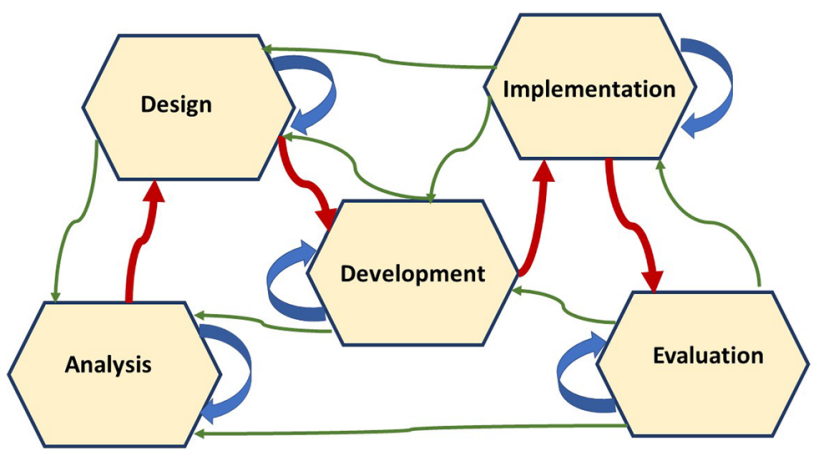

Fig. 1 The CADDIE model

instructionaldesign.org/models/addie.html) was responsible for poor-quality instructional design and productivity. There are many instructional design models. Andrews and Goodson (1980) performed an analysis of 40 instructional design models in 1980. There are at least twice that number floating around in cyberspace now. The ADDIE model is a basic generic design model that can be tailored and customized in many ways. Among other popular models is the PIE model (Planning, Implementation, Evaluation; see https:// www.cdc.gov/violenceprevention/pdf/chapter1-a.pdf) and Tennyson's (1993) 4th Generation Instruction Systems Development (ISD) model. The latter was based on empirical observations of what instructional designers do, and I find it especially useful in my teaching.

Because I am unable to resist the temptation to deviate, I shall add one more model and a comment about such models. The model I propose can be called CADDIE for Cyclic ADDIE. Essentially, it is a simplification of Tennyson's 4th generation ISD model that emphasizes the notion that design is essentially a dynamic and iterative process that sometime starts in the middle (for example, when updating an existing course). In the world of golf, a caddie is a person who assists the golfer. The caddie may carry the golfer's clubs (tools), as well as advise and encourage the golfer. The caddie's main task is to help the golfer have a successful day. The role of the instructional designer can be conceived as somewhat analogous to that of a caddie, as the main task is to help the learner have a successful experience. Instructional design should be accomplished in a manner consistent with what the instructor is likely to do or can do to help learners succeed. In addition to that analogy with a golf caddie, recall the " $C$ " in CADDIE stands for cyclic. There can be cycles within a particular aspect of instructional design as well as between various aspects of an instructional design effort (see Fig. 1). Tennyson's model explicitly recognizes that reality; unfortunately, it has not been widely used. One might conclude that instructional design researchers spend more time devising new models than paying careful attention to what counts-namely, helping to improve learning.

There really is no need for CADDIE as the ADDIE model was intended only to be a guide and is easily modified in many ways. My final comment in this section is that one ought not focus on the model itself. It is how the model is used that might have an impact on learning. After all, an instructional design model is a form of technology-a systematic and disciplined application of knowledge for a purpose valued by a community. What is the purpose? To help people learn. 


\section{Learning}

What about learning? I used a variation of Gagné's definition of learning earlierstable and persistent changes in what a person knows, believes, and/or can do. I remember one of my philosophy professors asking the doctoral students in a seminar what kinds of things there were in the universe. Being a slow learner with a simple mind, I asked him if we could restrict the discussion to the kinds of things that were in that room at that time at the University of Texas. Being an agreeable professor, he said sure, and we proceeded to have a discussion about ontology. Years later I met Gagné on the AIDA project, and he asked the group what kinds of things can be learned. Of course, we had all read Conditions of Learning and knew the kind of answer he was expecting. After naming variations of those things, I wanted to hear more about intellectual skills as I thought that intellectual skills had not been as well elaborated as they might be. In particular, by that time I was primarily interested in understanding how people came to develop expertise in solving complex, dynamic, and ill-structured problems which seemed pervasive (e.g., in environmental planning, engineering design, macro-economics, medical diagnosis, political policymaking, and technology integration). Those sorts of problems had many interrelated factors, with some nonlinear relationships, delayed effects, fuzzy or vague aspects, and changes in the situation likely to occur during a problem-solving effort. Yet some people manage to develop expertise that is widely recognized and potentially measurable.

I do not recall Gagné's initial response, but we had that discussion over a period of a couple of years. His views came to me in the form of what I now call a holistic perspective on learning. While our work with Air Force technical training involved students who had similar backgrounds and prior training, and we tested interim solutions at the Air Force Academy with students who were highly motivated and very well prepared, Gagné recognized that individual variations played a role in the development of expertise (although he did not like to use the phrase "developmental psychology" to refer to his work). He also noted that motivation was a critical factor in general, although the groups with which we interacted were generally highly motivated to do well. One insight that sticks with me was that, when faced with such complexity involving learning, it is worth focusing on that which seems to be critical to successful understanding. On several occasions, we thought that a learning task that we would classify as a psychomotor task turned out to be regarded by Gagné as an intellectual skill. One of the lessons used as an exemplar in GAIDA involved handcuffing, which we had initially classified as a psychomotor task. Gagné had recorded a non-commissioned officer teaching that lesson at an Air Force base in San Antonio. He told us to pay attention to the lesson. What is the instructor emphasizing? We watched again and then again. It seemed to us that what was emphasized were the bodily movements needed to handcuff a person correctly. Gagné slammed his fist on the table and shouted, "NO. Don't you see? Didn't you hear? The critical part of the task is to determine if the person being handcuffed is likely to resist. That is a discrimination task. Depending on that determination, the procedure changes. It is essential to get that right." Of course, he was correct. Gagné's views, along with those of the work already cited by Gagné and Merrill (1990), were further elaborated and embedded in van Merriënboer's (1997) fourcomponent instructional design (4C/ID) model. Yes, friends, there is another instructional design model ... and many more that I have failed to mention.

Since I have now taken one side trip, I cannot resist taking yet another. While working on AIDA in San Antonio, I met David Jonassen who was then at the University of Colorado-Denver. We shared a mutual interest in complex problems and problem solving, 
and I learned a great deal from Jonassen over the years, especially with regard to problem solving. I often refer my students to his work on developing instructional design models and practices to support learning to solve complex problems (see Jonassen 2000). I really miss those discussions. One of my earliest experiences as ETR\&D Development Editor involved a paper submitted by Jonassen. All three reviewers recommended rejecting it. How was I going to tell Dave his manuscript had been rejected. I agonized over that task for more than a week. Finally, I sent him the rejection notice in an email along with the anonymous reviews and with minimal wording of my own. The next day, he sent me an email thanking me for the review, saying that the comments were helpful and constructive, and that he would completely rework the paper and submit an entirely new paper. About 6 months later he submitted a new paper and I sent it out for review-to the same reviewers who had seen the first paper. This time it came back with recommendations for minor revisions and it was eventually published. I learned a great deal from that particular experience, including how to deal with tough decisions, how a good researcher thinks and takes criticism, and how to be a better Editor.

\section{Concluding remarks}

Well, I have had the great pleasure these last 15 years to witness great minds at work and benefit from the mentoring of many outstanding leaders in our field. I remember the detailed and supportive feedback that Steve Ross gave authors, including me (my first academic journal article in this field was in the Research Section of ETR\&D when Steve was Editor). I see Tristan Johnson now giving the same kind of detailed and supportive feedback to authors even though we now have many more submissions than when I started 15 years ago. I have not been so diligent in recent years, opting to let the reviewers speak for themselves. I have had the privilege to see reviewers mature since each reviewer receives an anonymous copy of the Editor's letter to the author with all three anonymous reviews. Many authors have thanked me over the years for the feedback they have received from reviewers, including authors whose manuscripts have been rejected. I especially remember a Canadian author whose paper went through seven revision cycles. I had suggested to that author after the third recommendation of major revisions and resubmission required that perhaps another venue might be more suitable. That author kindly thanked me but persisted and, after the fifth cycle, major revisions had changed to minor revisions and the paper was eventually published. The author approached me at a Journal Table Talk at AERA (American Educational Research Association) and thanked me profusely for the feedback over those seven revision cycles. That author is now one of the best reviewers we have at $E T R \& D$.

I am not sure how much I have accomplished, but I am certain that $E T R \& D$ reviewers have done a great deal in helping researchers and scholars learn how to tell their stories more effectively. In closing, I want to sincerely thank my many mentors, the Association of Educational Communications and Technology which sponsors ETR\&D (see www.aect. org), and Carol Bischoff, our senior editor at Springer (see http://www.springer.com/ education $+\% 26+$ language/learning $+\% 26+$ instruction/journal/11423), for the privilege awarded me these past 15 years. I have no doubt that $E T R \& D$ will continue to do well under the stewardship of Tristan Johnson, Patricia Young, and, Lin Lin, the new Development Editor. 


\section{References}

Andrews, D. H., \& Goodson, L. A. (1980). A comparative analysis of models of instructional design. Journal of Instructional Development, 3(4), 2-16.

Austin, J. L. (1962). How to do things with words (2nd ed.). Cambridge, MA: Harvard University Press. Retrieved from https://www.ling.upenn.edu/ rnoyer/courses/103/Austin.pdf.

Clark, R. E. (1994). Media will never influence learning. Educational Technology Research and Development, 42(2), 21-29.

Dewey, J. (1910). How we think. New York: D. C. Heath. Retrieved from https://archive.org/details/ howwethink000838mbp.

Gagné, R. M. (1985). The conditions of learning (4th ed.). New York: Holt, Rinehart, and Winston.

Gagné, R. M., \& Merrill, M. D. (1990). Integrative goals for instructional design. Educational Technology Research and Development, 38(1), 23-30.

Jonassen, D. H. (2000). Towards a design theory of problem solving. Educational Technology Research and Development, 48(4), 63-85.

Kozma, R. B. (1994). Will media influence learning? Reframing the debate. Educational Technology Research and Development, 42(2), 7-19.

Merrill, M. D. (2002). First principles of instruction. Educational Technology Research and Development, 50(3), 43-59. Retrieved from http://mdavidmerrill.com/Papers/firstprinciplesbymerrill.pdf.

Merrill, M. D., Li, Z., \& Jones, M. K. (1991). Instructional transaction theory. Educational Technology, 31(6), 7-12.

Nielsen, H. A. (1978). A game of India. Michigan Quarterly Review, 19, 111-115.

Tennyson, R. (1993). A framework for automating instructional design. In J. M. Spector, M. C. Polson, \& D. J. Muraida (Eds.), Automating instructional design: Concept and issues (pp. 191-217). Englewood Cliffs, NJ: Educational Technology Publications.

van Merriënboer, J. J. G. (1997). Training complex cognitive skills: A four-component instructional design model for technical training. Englewood Cliffs, NJ: Educational Technology Publications.

Jonathan Michael Spector is Professor and Former Chair of Learning Technologies at the University of North Texas. He was previously Professor of Educational Psychology and Instructional Technology at the University of Georgia. Prior to that, he was Associate Director of the Learning Systems Institute and Professor of Instructional Systems at Florida State University. He served as Chair of Instructional Design, Development and Evaluation at Syracuse University and was Director of the Educational Information Science and Technology Research Program at the University of Bergen. He earned a Ph.D. in Philosophy from The University of Texas at Austin. His research focuses on intelligent support for instructional design, assessing learning in complex domains, and technology integration in education. Dr. Spector served on the International Board of Standards for Training, Performance and Instruction (ibstpi) as Executive Vice President; he is a Past President of the Association for Educational and Communications Technology as well as a Past Chair of the Technology, Instruction, Cognition and Learning Special Interest Group of AERA; he is also an active member of AERA's Instructional Technology and Learning and Technology SIGs. He has been editor of Educational Technology Research \& Development for 15 years, and serves on numerous other editorial boards. He edited the third and fourth editions of the Handbook of Research on Educational Communications and Technology, as well as the Encyclopedia of Educational Technology, and has more than 150 publications to his credit. 